\title{
Effect of Processing Methods on Phytic Acid Content in Selected White Finger Millet Varieties
}

\author{
Sneha Shigihalli ${ }^{1 *}$, Usha Ravindra ${ }^{1}$ and P. Ravishankar ${ }^{2}$ \\ ${ }^{1}$ Department of Food Science and Nutrition UAS, GKVK, Bengaluru, Karnataka, India \\ ${ }^{2}$ AICSMIP, PC unit University of Agricultural Sciences, GKVK, Bengaluru, Karnataka, India \\ *Corresponding author
}

\section{A B S T R A C T}

\begin{tabular}{|l|}
\hline Ke y w o r d s \\
Variety, White \\
finger millet, Phytic \\
acid, Malting, \\
Popping, Soaking \\
\hline Article Info \\
\hline $\begin{array}{l}\text { Accepted: } \\
\text { 17 January } 2018 \\
\text { Available Online: } \\
\text { 10 February } 2018\end{array}$ \\
\hline
\end{tabular}

The present investigation was carried out to study the effect of different processing methods (soaking, malting and popping) on phytic acid content in selected (GE 6834-1, KMR-344 and DHWFM 11-3) white finger millet varieties procured from AICSMIP Bengaluru. Results from the study revealed that, phytic acid concentration in soaked samples was found with a mean ranging from $250 \mathrm{mg}$ (12hrs soaking), $241 \mathrm{mg}$ ( $24 \mathrm{hrs}$ of soaking) and $221 \mathrm{mg} / 100 \mathrm{~g}$ (48 hrs of soaking). While in malted samples of white finger millet varieties ranged from $235 \mathrm{mg}$ (12 hrs malted), $190 \mathrm{mg}$ ( $24 \mathrm{hrs}$ malted) and $132 \mathrm{mg} / 100 \mathrm{~g}$ (48 hrs malted). However the phytic acid content in popped samples varied significantly with a mean of 239mg (1 hr soaked and popped), 230mg (4 hrs soaked and popped) and $221 \mathrm{mg}$ ( $8 \mathrm{hrs}$ soaked and popped). Processing methods significantly $(\mathrm{P}=$ $0.05)$ reduced the phytic acid content in the studied varieties and was found in the order malted>popped>soaked, however successive decline was observed with increase in interval of soaking, malting and popping. Among the varieties, KMR 344 recorded significantly $(\mathrm{P}=0.05)$ lowest phytic acid in all processing methods employed except for popping (GE6834-1).

\section{Introduction}

Small millets are a group of small seeded cereal crops belonging to the family Poaceae, grown for food, feed or forage and cultivated mostly in developing countries, are indigenous to many parts of the world; most likely had an evolutionary origin in tropical western Africa, where they exist in wild and cultivated forms (FAO 1995). They include finger millet (Eleusinecoracana), foxtail millet (Setariaitalica), kodomillet (Paspalum scrobiculatum), proso millet (Panicum miliaceum), barnyard millet (Echinochloa frumentacea) and little millet (Panicum sumatrense). The finger millet grains are quite small and vary in colour from dark brown to nearly white depending on the variety (Kurien et al., 1959). The crop is highly valued in part due to its notably high calcium, iron, zinc content and dietary fibre, which is grown mainly by subsistence farmers and serves as a food security crop because of its highnutritional value and excellent storage qualities, enabling safe storage for several years, making it a traditional component of 
farmers risk-avoidance strategies in droughtprone areas where environmental stresses, particularly hot and dry conditions, limit the production of other crops (Naylor et al., 2004).

Apart from its excellent nutritional values, it possess other health benefits such as antimicrobial, anti-inflammatory, antiviral, anticancer, antiplatelet aggregation and inhibitory activities on cataract formation (Viswanath et al., 2009). Furthermore, Shobana and Malleshi (2007) showed that, phenolic extracts from finger millet seed coat are responsible for inhibiting enzymes such as $\alpha$-glucosidase and pancreatic amylase, thus indicating their therapeutic potential for managing postprandial hyperglycemia. It also has significant medicinal properties for treatment and prevention of cancer initiation. In India, for instance, it is used traditionally as remedy for leprosy, liver disease, measles, pneumonia and small pox (Birhanu et al., 2015).

With all these beneficial properties, maximum utilization of the nutrient potential of the millet is limited by the presence of antinutrients like phytates, tannins and enzyme inhibitors. The dietary phytic acid binds not only with the seed derived minerals but also with other endogenous minerals, encountered in the digestive tract. So simple processing techniques such as soaking, germination, malting, fermentation and puffing may help in reducing the anti-nutritional factors. Hence, the present study was carried out to know the effect of processing methods on phytic acid content in selected white finger millet varieties.

\section{Materials and Methods}

White finger millet varieties (WFM) [GE 6834-1, KMR 344, DHWFM 11-3], were procured from AICSMIP, PC unit, GKVK,
Bengaluru. Grains were sorted to remove stones, dirt and any other foreign particles. They were stored in an air tight polythene pouches until ready for processing.

\section{Milling}

Raw clean and moisture free grains of white finger millet varieties were powdered in flour mill and stored in air tight polythene cover for further analysis.

\section{Soaking}

In soaking treatment the raw and clean grains of three selected white finger millet varieties were soaked in distilled water in a conical flask at different intervals of 12 hour, 24 hour and 48 hour at room temperature. The soaking water was discarded and then the soaked grains were dried at $60^{\circ} \mathrm{C}$ till it attains constant moisture content. The dried seeds were ground to fine powder and stored in air tight polythene cover for further analysis.

\section{Malting}

In malting treatment the raw and clean grains of three selected white finger millet varieties were steeped in distilled water over night in a conical flask at room temperature and germinated under controlled conditions on moist muslin cloth at $25{ }^{\circ} \mathrm{C}$ in a B.O.D. incubator at intervals of 12 hour, 24 hour and 48 hour. Germinated seeds were taken out and dried at $60^{\circ} \mathrm{C}$ in a hot air-oven for $6 \mathrm{~h}$ till it attains constant moisture content; growth portions were removed by gentle rubbing manually. Devegetated seeds were weighed, powdered and used for the further experiments.

\section{Popping (Malleshi et al., 1986)}

After determining the moisture in the sample by hot air oven drying method, water was 
sprinkled on the grain to raise the moisture content to 19 per cent and grains were equilibrated in a closed airtight container for a period of $1 \mathrm{hr}, 4 \mathrm{hrs}$ and $8 \mathrm{hrs}$ prior to popping. After that, the equilibrated grains were added in an iron frying pan, the temperature of which was maintained at $175-200^{\circ}$ C. When popping sound was stopped the pan was removed from the flame and popped millets were powdered andused for further analysis

\section{Per cent germination (Aykroyd and Doughty, 1964)}

100 seeds were placed in a petriplate on a filter paper dampened with water and the lid was closed and kept in incubator and allowed to germinate for $24 \mathrm{hrs}$. Further germinated seeds were counted and expressed in percentage.

Per cent malt recovery (Malleshi et al., 1986)

$100 \mathrm{~g}$ of finger millet was washed with water for 5 times and soaked in water overnight. Excess water was drained, seeds were tied in a muslin cloth and weight was kept on it. These seeds were germinated at $27 \pm 3^{\circ} \mathrm{C}$ for $24 \mathrm{hr}$ and dried in shade for 2 days. The malted ragi seeds were grounded into flour by using the flour mill and the yield of flour was taken as malt recovery.

Per cent popping (Malleshi and Desikachar, 1981)

After determining the moisture in the sample by oven drying methods, water was sprinkled on the grain to raise the moisture content to 19 per cent and grains were equilibrated in a closed airtight container and grains equilibrated in a closed airtight container for 1 $\mathrm{hr} 4 \mathrm{hrs}$, and $8 \mathrm{hrs}$ prior to popping. After that the equilibrated grain were put on hot frying pan, the temperature of which was maintained at $175-200^{\circ} \mathrm{C}$. When popping sound was stopped the pan was removed from the flame. Unpopped grains were separated by sieving with 40 mesh (BSS) sieve. The yield of popped flour was taken as the percent popping.

\section{Estimation of phytic acid (Sadashivam and Manickam, 1991)}

The estimation of phytic acid was based on the principle that the phytate is extracted with trichloroacetic acid and precipitated as ferric salt. The iron content of the precipitate was determined colorimetrically and the phytate phosphorous content calculated from this value assuming a constant $4 \mathrm{Fe}$ : 6 molecular ratios in the precipitate. Phytates were estimated as phyticacid and phytate phosphorous.

Phytate $\mathrm{P}(\mathrm{mg} / 100 \mathrm{~g})=(\mu \mathrm{g} \mathrm{Fe} \times 15 \times 1 / \mathrm{Wt}$. of sample $(\mathrm{g})) \times(1 / 100)$

\section{Statistical analysis}

Three samples for each parameter were prepared, each sample was analyzed in triplicate and the values were then averaged. Data were assessed by analysis of variance (ANOVA)

\section{Results and Discussion}

The germination is an important unit operation which needs greater attention. During germination process, the hydrolytic enzymes bring changes in the endosperm. Some of the vitamins are also synthesized and the bioavailability of minerals increases. Thus under present study germination per cent was studied and the results from the study is presented in Table 1 per cent germination of selected white finger millet varieties under the study ranged from 94 to 97 which were in tune with findings of the study by Kumari and 
Srivastava (2000) and Hiremath (2011). Malting of finger millet improves its digestibility, sensory and nutritional quality as well as pronounced effect in lowering the antinutrients (Desai et al., 2010). Finger millet has some of the inherent qualities which make it superior compared to other cereals and also qualify for malting and preparation of malted foods. It is resistant to fungal infection and elaboration of alpha and beta amylase during germination and during roasting/kilning a desirable aroma as well as is developed which makes it an ideal grain for malt foods. Per cent malt recovery of selected white finger millet varieties varied from 78 to 83 per cent. This observation is consistent with the findings of Hiremath (2011) Malleshi and Klopfenstein (1998) the variation in malt recovery may be due to the moisture and fiber content in the varieties. A study conducted by Shukla et al., (1986) on finger millet puffing yield found that puffing yield ranged from 66 to 95.30 per cent. But the popping per cent under study ranged from 68 to 84 per cent, which is in tune with the findings of the study conducted by Shukla et al., (1986) on eight varieties of finger millet for puffing yield. Popping or puffing of finger millet is one of the popular traditional methods and the popped millet and its flour is a ready to eat product with pleasing texture and appealing flavour. Popping improves the nutritional value by inactivating some of the antinutritional factors and thereby enhancing the protein and carbohydrate digestibility (Nirmala et al., 2000); it also enhances the appearance, colour, taste and aroma of the processed raw material. The flour can be used for different types of ready to eat food preparations depending upon the taste and likings.

Phytate has long been recognized as an antinutritional factor especially known as a chelating agent that reduces the bioavailability of divalent cations of major minerals such as $\mathrm{Ca}$ and $\mathrm{P}$ and trace elements such as $\mathrm{Zn}, \mathrm{Fe}$,
$\mathrm{Cu}$ and $\mathrm{Mn}$, which are known to limit the utilization of it as a food or feed. Decrease of phytic acid is very advantageous, due to its influence on nutrition; therefore interest has grown to reduce its antinutritional effects (Abdelrahaman et al., 2007), by means of certain biological or thermal treatments, such as appertisation allow phytate content to be reduced. The most effective treatments are fermentation and germination but their application remains limited because of the additional workload they imply or the particular organoleptic properties they induce. Soaking, malting, popping are important traditional methods used to reduce phytic acid. Data on phytic acid concentration of differently processed samples of selected white finger millet are presented in Table 2. Phytic acid content in raw white finger millet samples varied from 248 to $291 \mathrm{mg} / 100 \mathrm{~g}$ which is in tune with findings of Shashi (2005) the highest was noticed in DHWFM $11-3$ (291mg) and least was in KMR $344(248 \mathrm{mg} / 100 \mathrm{~g})$. Soaking is a simple technological treatment that is often used by mothers to prepare complementary foods at home. Moreover, it can be a simple prolongation of the obligatory washing of the seeds and can also have other advantages, such as facilitating dehulling or swelling of seeds. The phytic acid concentration tends to decline in soaked samples ranging from 232 to $274 \mathrm{mg}$ (12hrs soaking), 220 to $267 \mathrm{mg}$ (24 hrs of soaking) and 203 to $246 \mathrm{mg} / 100 \mathrm{~g}$ (48 hrs of soaking). Among the varieties maximum decline was observed in KMR 344 variety in all the three different time intervals of soaking. The descending orders of phytic acid content at different intervals of soaking and in selected varieties were 12 hrs $>24 \mathrm{hrs}>48 \mathrm{hrs}$ and DHWFM 11-3>GE $6834-1>$ KMR 344 respectively. Similar trend was observed in study reported by Lestienne et al., (2005) where soaking whole seeds for $24 \mathrm{~h}$ led to significant $(\mathrm{P} \leq 0.05)$ reduction in the phytate content of millet. 
Table.2 Effect of processing methods on phytate content $\mathrm{mg} / 100 \mathrm{~g}$ in selected white finger millet varieties

\begin{tabular}{|c|c|c|c|c|c|c|c|c|c|c|c|c|c|}
\hline \multirow[t]{2}{*}{ Varieties } & \multirow{2}{*}{$\begin{array}{l}\text { Raw } \\
\text { O hr }\end{array}$} & \multicolumn{6}{|c|}{ Soaked } & \multicolumn{6}{|c|}{ Malted } \\
\hline & & $\begin{array}{c}12 \\
\text { hrs }\end{array}$ & $\begin{array}{l}\text { Per cent } \\
\text { decreas } \\
\text { e over } \\
\text { raw }\end{array}$ & $24 \mathrm{hrs}$ & $\begin{array}{l}\text { Per cent } \\
\text { decrease } \\
\text { over raw }\end{array}$ & $\begin{array}{c}48 \\
\text { hrs }\end{array}$ & $\begin{array}{c}\text { Per cent } \\
\text { decreas } \\
\text { e over } \\
\text { raw }\end{array}$ & $12 \mathrm{hrs}$ & $\begin{array}{c}\text { Per cent } \\
\text { decrease } \\
\text { over } \\
\text { raw }\end{array}$ & $24 \mathrm{hrs}$ & $\begin{array}{c}\text { Per cent } \\
\text { decreas } \\
\text { e over } \\
\text { raw }\end{array}$ & $48 \mathrm{hrs}$ & $\begin{array}{l}\text { Per cent } \\
\text { decrease } \\
\text { over raw }\end{array}$ \\
\hline GE 6834-1 & $260^{b}$ & $245^{b c}$ & 5.77 & $236^{\mathbf{b B}}$ & 9.23 & $215^{\mathbf{b A}}$ & 17.31 & $229^{b c}$ & 11.92 & $185^{\mathbf{b B}}$ & 28.85 & $128^{\mathrm{bA}}$ & 50.77 \\
\hline KMR 344 & $248^{a}$ & $232^{\mathrm{aC}}$ & 6.45 & $220^{\mathbf{a B}}$ & 11.29 & $203^{\mathbf{a A}}$ & 18.14 & $218^{\mathrm{aC}}$ & 12.10 & $172^{\mathbf{a b}}$ & 30.64 & $120^{\mathbf{a A}}$ & 51.61 \\
\hline DHWFM 11-3 & $291^{c}$ & $274^{\mathrm{cC}}$ & 5.50 & $267^{\mathrm{cB}}$ & 8.25 & $246^{\mathrm{cA}}$ & 15.46 & $258^{\mathrm{cC}}$ & 11.34 & $212^{\mathbf{c B}}$ & 27.15 & $147^{\mathbf{c A}}$ & 49.48 \\
\hline Mean & 266 & 250 & 5.90 & 241 & 9.59 & 221 & 16.97 & 235 & 11.78 & 190 & 28.88 & 132 & 50.62 \\
\hline
\end{tabular}

Note: Values are mean triplicates of samples

Superscript in capital letters (A, B \& C) indicates the significant difference between the periods within the processing method

Superscript in small letters indicates $(a, b \& c)$ significant difference between the varieties, within the processing methods and period

Table.3 Effect of popping on phytate content $\mathrm{mg} / 100 \mathrm{~g}$ in selected white finger millet varieties

\begin{tabular}{|c|c|c|c|c|c|c|c|}
\hline \multirow[t]{2}{*}{ Varieties } & \multirow{2}{*}{$\begin{array}{l}\text { Raw } \\
\text { O hr }\end{array}$} & \multicolumn{6}{|c|}{ Popped } \\
\hline & & $1 \mathrm{hr}$ & $\begin{array}{c}\text { Per cent } \\
\text { decrease over } \\
\text { raw }\end{array}$ & $4 \mathrm{hrs}$ & $\begin{array}{c}\text { Per cent } \\
\text { decrease over } \\
\text { raw }\end{array}$ & 8 hrs & $\begin{array}{c}\text { Per cent } \\
\text { decrease over } \\
\text { raw }\end{array}$ \\
\hline GE 6834-1 & $260^{\mathrm{bD}}$ & $219^{\mathrm{aC}}$ & 15.76 & $210^{\mathbf{a b}}$ & 19.23 & $202^{\mathbf{a A}}$ & 22.30 \\
\hline KMR 344 & $248^{\mathrm{aD}}$ & $228^{\mathbf{b C}}$ & 8.06 & $220^{\mathbf{b B}}$ & 11.29 & $208^{\mathbf{b A}}$ & 16.12 \\
\hline DHWFM 11-3 & $291^{\text {cD }}$ & $270^{\mathrm{cC}}$ & 7.21 & $261^{\mathbf{c B}}$ & 10.30 & $253^{\mathrm{cA}}$ & 13.06 \\
\hline Mean & 266 & 239 & 10.34 & 230 & 13.60 & 221 & 17.16 \\
\hline \multicolumn{4}{|c|}{$\mathrm{CD}(\mathrm{P} \leq \mathbf{0 . 0 5})$ means between varieties and between periods : 2.87} & \multicolumn{4}{|c|}{$\operatorname{SEm} \pm(0.05): 1.19$} \\
\hline
\end{tabular}

Note: Values are mean triplicates of samples

Superscript in capital letters (A, B \& C) indicates the significant difference between the periods within the processing method

Superscript in small letters indicates $(a, b \& c)$ significant difference between the varieties, within the processing methods and period 
Table.1 Study of processing methods on selected white finger millet varieties

\begin{tabular}{|c|c|c|c|}
\hline Varieties & Germination (\%) & Malt recovery (\%) & Popping (\%) \\
\hline GE 6834-1 & 97 & 80 & 84 \\
\hline KMR 344 & 96 & 83 & 76 \\
\hline DHWFM 11-3 & 94 & 78 & 68 \\
\hline
\end{tabular}

Malting of finger millet improves its digestibility, sensory and nutritional quality as well as has pronounced effect in lowering the antinutrients. The inherent qualities of finger millet make it superior compared to other cereals and also qualify for malting and preparation of malted foods for infants and children. The mean phytic acid content in malted samples of white finger millet varieties ranged from $235 \mathrm{mg}$ (12 hrs malted), 190mg (24 hrs malted) and $132 \mathrm{mg} / 100 \mathrm{~g}$ (48 hrs malted) significant decline in phytic acid was observed in samples under study with increase in malting interval. Highest decline was observed in $48 \mathrm{hrs}$ of malting process and among the varieties significant reduction was observed in KMR 344 at all intervals of malting making it more suitable for malt preparation. The decline order of phytic acid content in varieties was DHWFM 11-3 > GE 6834-1> KMR 344.This observation is consistent with the findings of Hiremath (2011) on finger millet varieties malted for 24 hours. The decrease in phytic acid content during malting may be attributed to the leaching out during hydration or result of increase in phytase activity during germination (Osman, 2009). Similar trend was also observed by Wadikar et al., (2006)

Popping or puffing is a simple processing technique of cereals to prepare ready to eat products. Popped grain is crunchy, porous and a precooked product. Popped grains especially of finger millet posses a pleasant aroma and acceptable taste. This process improves the nutritional value by inactivating some of the anti- nutritional factors and thereby enhancing the protein and carbohydrate digestibility (Nirmala et al., 2000) phytic acid content in popped samples is presented in Table 3 . The phytic acid content in popped samples varied significantly with a mean of $239 \mathrm{mg}$ (1 hr soaked and popped), 230mg (4 hrs soaked and popped) and $221 \mathrm{mg}$ (8 hrs soaked and popped). The significant decline was observed with increase in soaking and popping time. The results are in line with the findings of Hiremath (2011). Processing methods such as soaking, malting and popping significantly reduced the phytic acid content in the selected varieties under study the mean phytic acid content of raw samples was $266 \mathrm{mg} / 100 \mathrm{~g}$. For soaked, malted and popped samples successive decline in phytic acid was observed with increase in interval of soaking, malting and popping. Maximum reduction of phytic acid was observed in variety KMR 344 in all the processing methods employed except for popping with a mean of 232 to $203 \mathrm{mg}$ (in 12 to $48 \mathrm{hrs}$ soaked samples), 218 to $120 \mathrm{mg}$ (12 to $48 \mathrm{hrs}$ of malted samples). While GE 6834-1 had lower phytic acid in popping method, with a mean of 219 to $202 \mathrm{mg} / 100 \mathrm{~g}$ (at $1 \mathrm{hr}$ to $8 \mathrm{hrs}$ of popped samples). Among the processing methods malting method significantly reduced the phytic acid content in all the selected varieties under study followed by popping and soaking methods.

\section{Acknowledgment}

The authors acknowledge the All India Coordinated Small Millet Improvement Programme (AICSMIP) UAS, GKVK, Bengaluru-560065 for providing the white finger millet varieties to carry out the research.

\section{References}

Abdelrahaman, S. M., Elmaki, H. B., Idris, W. H., Hassan, A. B., Babiker, E. E. and Eltinay, A. 
H. 2007. Antinutritional factor content and hydrochloric acid extractability of minerals in pearl millet cultivars as affected by germination. International Journal of Food sciences and Nutrition. 58(1): 6-17.

Aykroyd, D. R. and Doughty. J. 1964. Legumes in human nutrition, Rome. Food and Agricultural Organisation, pp: 69-80

Birhanu, W. T., Chaueby, A, K., Teklemariam, T. T., Dewu B. B. M., Oladipo, M. O. A., Ahmed, Y. A. and Abubakr, N., 2015, Analysis of essential elements in Ethiopian finger millets (Eeleusine coracanda) by instrumental neutron activation analysis (INAA). International Journal of Basic and Applied Sciences.4 (1):82-88.

FAO (Food and Agriculture Organization) 1995.Sorghum and millets in human nutrition. Rome, Italy.

Hiremath, S. P. 2011. Physico-chemical characteristics of raw, malted and popped finger millet varieties. M. Sc Thesis, University of Agricultural Sciences, Bangalore.

Kumari, S. and Srivastava, S. 2000. Nutritive value of malted flours of finger millet genotypes and their use in the preparation of burfi. J.Food.Sci.Technol., 37(4): 419-422.

Kurien, P. P., Joseph, K., Swaminathan, M. and Subrahmanyan, V. 1959. The distribution of nitrogen, calcium and phosphorous between the husk and endosperm of ragi (Eleusine coracana).Food Science (Mysore).8: 353-355.

Lestienne, I., Icard-Verniere, C., Mouquet, C., Picq, C. and Treche, S. 2005. Effects of soaking whole cereal and legume seeds on iron, zinc and phytate contents. Food Chemistry.89: 421-425.

Malleshi, N. G. and Deskachar, H. S. R. (1981). Varietal Differences in puffing quality of ragi. J. Food, Sci Techno.1, 18 (1): 30-32.

Malleshi, N. G. Deskachar, H. S. R. and Tharanatha, R. N. (1986). Physicochemical properties of native and malted finger millet and foxtail millet starches, CFTRI. Starches Sterke
(Germany, J. K.) 38(6): 202-205.

Malleshi, N.G. and Klopfenstein, C.F. (1998).Nutrient composition and amino acid contents of malted sorghum, pearl millet and finger millet and their milling fractions. Food. Sci Technol. Mysore. 35(3):247-249.

Naylor, R. L., Falcon, W. P., Goodman, R. M., Jahn, M. M., Sengooba, T. Tefera, H. and Nelson, R. J. (2004). Biotechnology in the developing world, a case for increased Investments in orphan crops. Food Policy.29: 15-44.

Nirmala, M., Subba Rao, M. V. S. S. T. and Murlikrishna, G. 2000. Carbohydrates and their degrading enzymes from native and malted finger millet (Ragi, Eleusine coracana, Indaf15). Food Chem. 69:175-180.

Osman, A. A. 2009. Studies on using Sesbania forage in feeding of growing rabbit. Agric.Res. J. (Egypt) 2. http.//arjsuc.webs. com/20092.htm

Sadashivam, S. and Manickam, A.1991. Second edition, Biochemical methods. New age International Publishers, pp193-194

Shashi, B.K., 2005, M Sc. Thesis, University of agricultural Sciences, Bangalore.

Shobana, S. and Malleshi, N. G. (2007) Preparation and functional properties of decorticated finger millet (Eleusine coracana). Journal of Food Engineering.79:529-538.

Shukla, S. S., Gupta, O.P., Sharma, Y.K. and Swarkar, N.S. 1986. Puffing quality characteristic of some ragi cultivars. J.Food.Sci Technol. 23(6):265-267.

Viswanath, V., Urooj, A. and Malleshi, N. G. 2009. Evaluation of antioxidant and antimicrobial properties of finger millet polyphenols (Eleusine coracana). J. Food Chem. 114(1):340-346.

Wadikar, D., Vasidish, C., Premavalli, K. and Bawa, A. 2006. Effect of variety and processing on anti-nutrients in finger millet. Journal of Food Science and Technology.43(4): 370-373.

\section{How to cite this article:}

Sneha Shigihalli, Usha Ravindra and Ravishankar, P. 2018. Effect of Processing Methods on Phytic Acid Content in Selected White Finger Millet Varieties. Int.J.Curr.Microbiol.App.Sci. 7(02): 1829-1835. doi: https://doi.org/10.20546/ijcmas.2018.702.220 